\title{
RECENZJE
}

Forum Pedagogiczne UKSW

$2 / 2012$

\author{
SEBASTIAN TABOE
}

WSP TWP, Warszawa

\section{ANDRZEJ RYK, W POSZUKIWANIU PEDAGOGICZNEGO ARCHÉ. ZARYS SYSTEMÓW PEDAGOGICZNYCH, WYDAWNICTWO NAUKOWE UNIWERSYTETU PEDAGOGICZNEGO, KRAKÓW 2012, SS. 333}

Związki pedagogiki i filozofii są zauważalne szczególnie po 1989 roku. Zadaniem Andrzeja Ryka było te związki wykazać w swojej monografii. Zdaniem Autora praktycznie każda koncepcja czy system pedagogiczny są oparte na fundamencie filozoficznym. To rodzi postulat, aby budować pedagogikę opartą na rozumieniu własnej tożsamości (s. 12). Pedagogice jest jeszcze jednak potrzebna filozofia rozumiana jako sztuka refleksji (s. 14). Autor próbuje także uzmysłowić czytelnikom, że w pedagogice występuje deficyt dociekań filozoficznych, co w dalszej konsekwencji może doprowadzić do braku zrozumienia pedagogiki, zwłaszcza jej metapedagogicznych dociekań (s. 14). Celem napisania pracy jest „próba przedstawienia filozoficznych inspiracji w pedagogice oraz rekonstrukcji podstawowych systemów pedagogicznych jako zasadniczych rodzajów pedagogicznego arché" (s. 14). Badania prowadzone na gruncie filozofii mogą stać się fundamentem badań pedagogicznych.

Zapoznając się z pracą należy zwrócić uwagę na słowo użyte w tytule monografii - arché. Autor w swych intelektualnych dociekaniach próbuje ustalić praprzyczynę filozoficznych inspiracji w pedagogice. Budowanie podstawowych systemów pedagogicznych należy rozpocząć od zrozumienia, czym jest arché. Również zrozumienie tego pojęcia może 
przyczynić się do zrekonstruowania nurtów pedagogicznych. Niniejsza praca wyjaśnia, na czym polega spór o paradygmatyczność w pedagogice oraz w jaki sposób filozofia może wciąż inspirować do badań nad wychowaniem.

Praca składa się z czterech rozdziałów. Pierwszy rozdział poświęcony jest podstawowym związkom, jakie występują między pedagogiką a filozofią. Autor dokonuje próby odpowiedzi na pytanie dotyczące tego, gdzie należy szukać pozapedagogicznych źródeł tego, co pedagogiczne. Zdaniem Ryka odpowiedzi należy szukać w codziennym doświadczeniu, ponieważ „w nim [...] dokonuje się pierwszy rodzaj obserwacji wchodzących w skład tzw. wiedzy potocznej, wiedzy zdroworozsądkowej” (s. 19). Każdy człowiek tkwi w pozapedagogicznym doświadczaniu rzeczywistości, które może stać się przedmiotem refleksji oraz fundamentem działania o charakterze pedagogicznym.

Rozdział drugi monografii zawiera rozważania poświęcone zagadnieniu rozumienia systemu oraz ukazuje podstawowe idee ontologiczno-epistemologiczne jako źródła systemów pedagogicznych. Ryk dokonał także ekspozycji podstawowych obszarów analizy w kontekście wybranych kierunków filozoficznych. Autor uważa także, iż „poszczególne kierunki filozoficzne prezentujące zróżnicowany sposób rozumienia i interpretacji otaczającej człowieka rzeczywistości, a w konsekwencji i jego samego - jako istniejącego podmiotu wpływają na sposób konieczny do kreowania różnych odpowiedzi dotyczących poszczególnych elementów teorii pedagogicznej” (s. 64).

Kolejny rozdział jest próbą ukazania podstawowych źródeł kształtowania się poszczególnych systemów pedagogicznych. Autor dokonał tu analizy historycznej takich systemów pedagogicznych, jak: pedagogika esencjalistyczna, podmiotowa, przedmiotowa, konstruktywistyczna oraz ponowoczesna. Jest to najobszerniejsza część pracy, w której Ryk postanowił odsłonić podstawowe źródła filozoficzne analizowanych systemów pedagogicznych. Dokonał także zobrazowania wyodrębnionych systemów pod kątem teorii i praktyki pedagogicznej.

Ostatni rozdział monografii to syntetyczne ujęcie wybranych przez autora określonych systemów w wybranych obszarach teorii pedago- 
gicznej. Ujęcie to przyjmuje różnorodną perspektywę metodologiczną. Ryk postanowił istniejące prądy, nurty oraz kierunki analizować poprzez zastosowanie kryterium ontologiczno-epistemologicznego. Poza tym rozdział zawiera syntezę przeprowadzonych analiz. Ta synteza ogranicza się przede wszystkim do sformułowania założenia o istnieniu czterech podstawowych systemów: pedagogiki esencjalistycznej, pedagogiki przedmiotowej, podmiotowej oraz konstruktywistycznej. Autor postanowił także zanalizować wymienione systemy z punktu założeń ontologicznych, epistemologicznych, aksjologicznych, metodologicznych, celu badań, natury wiedzy, sposobu gromadzenia wiedzy oraz koncepcji i roli badacza w procesie poznawania (s. 287).

Praca Ryka jest wynikiem badań podstawowych, które autor prowadził nad fundamentalnymi ( $\mathrm{z}$ tego powodu występuje słowo arché w tytule) kwestiami poruszanymi w pedagogice. Choć tytuł pracy może sugerować, że analizy, jakie zostały przeprowadzone przez autora, będą miały charakter pedagogiczny, jednak zdecydowaną większość stanowią analizy filozoficzne. Praca w wymiarze epistemologicznym ma duże znaczenie dla badaczy-pedagogów. Ryk pragnie zainspirować wielu pedagogów do badań w wymiarach, które do tej pory były zaniedbane. Zdaniem autora analizę rzeczywistości należy wzbogacić o perspektywę pedagogiczną.

Ryk dokonał nowego sposobu zaklasyfikowania istniejących systemów pedagogicznych. Fundamentem klasyfikacji stała się perspektywa historyczno-filozoficzna. Należy także zaznaczyć, że autor uporządkował bogatą rzeczywistość pedagogiczną, stosując kryterium ontologiczno-epistemologiczne. Zróżnicowane i złożone struktury systemów pedagogicznych zostały ukazane w sposób klarowny i jasny, a jednocześnie nowatorski. Nikt przedtem nie próbował dokonać analizy istniejących systemów pedagogicznych poprzez poszczególne szkoły filozoficzne: idealizm, realizm, egzystencjalizm, naturalizm, pragmatyzm i filozofię krytyczną.

Niniejsza monografia powinna znaleźć się w wykazach bibliograficznych dotyczących metodologii badań pedagogicznych, ponieważ przybliża warsztat dokonywania rekonstrukcji podstawowych systemów pe- 
dagogicznych w oparciu o filozoficzną inspirację jako zasadniczy rodzaj pedagogicznego arché. Ważne jest także to, co sam autor stwierdza na samym końcu opracowanej przez siebie cennej monografii: „Prezentowana monografia nie rości sobie prawa do wyczerpania zadanego tematu. [...] Nadal wielu pedagogów prezentuje raczej hermetyczną niż hermeneutyczną postawę w stosunku do rozumienia prawdy o człowieku" (s. 307). Systemy pedagogiczne zawierają określoną prawdę o człowieku oraz ukazują horyzont, w jakim przyszło mu żyć. 